\title{
A new species of Proceratophrys (Anura: Cycloramphidae) from western Brazil
}

\author{
ROBSON W. ÁVILA ${ }^{1,4}$, RICARDO A. KAWASHITA-RIBEIRO² \& DRAUSIO H. MORAIS ${ }^{3}$ \\ ${ }^{1}$ Universidade Regional do Cariri, Centro de Ciências Biológicas e da Saúde, Departamento de Ciências Biológicas, Campus do \\ Pimenta, Rua Cel. Antonio Luiz, 1161, Bairro do Pimenta, 63105-100, Crato, CE, Brazil \\ ${ }^{2}$ Universidade Federal de Mato Grosso, Instituto de Biociências, Coleção Zoológica de Vertebrados. Avenida Fernando Corrêa da \\ Costa s/n. CEP 78060-900, Cuiabá, MT, Brazil \\ ${ }^{3}$ Departamento de Parasitologia, Instituto de Biociências, UNESP, Distrito de Rubião Jr., s/no , CEP 18618-000, Botucatu, SP, Brazil \\ ${ }^{4}$ Corresponding author. E-mail: robsonavila@gmail.com
}

\begin{abstract}
A new species of Proceratophrys cristiceps group is described from western Brazil. The new species is characterized by absence of prominent palpebral appendages and postocular swellings, males measuring $44.2 \pm 2.1 \mathrm{~mm} \mathrm{SVL} \mathrm{(41.1-47.3}$ $\mathrm{mm}$ ) and females $56.4 \pm 2.8 \mathrm{~mm} \mathrm{SVL}(52.7-59.8 \mathrm{~mm})$, snout rounded in dorsal , and obtuse in lateral views, dorsal skin uniformly rugose, with no elevated warts, and tympanum defined as a depression on the skin. The new species was found in Guaporé river drainage, a highly impacted area due to the construction of water dams.
\end{abstract}

Key words: Proceratophrys cristiceps group, Amphibia, morphology, Cerrado, Amazon, Proceratophrys strussmannae sp. nov.

\section{Introduction}

The genus Proceratophrys Miranda-Ribeiro (1920) actually is composed by 22 species, distributed in Brazil, Argentina and Paraguay (Prado \& Pombal, 2008; Amaro et al., 2009). Three species groups, have been recognized based on morphological similarity: the P. boiei group (sensu Prado \& Pombal, 2008), characterized by prominent palpebral appendages, which includes P. appendiculata (Günther), P. boiei (Wied-Neuwied), P. melanopogon (Miranda-Ribeiro), P. laticeps Izecksohn \& Peixoto, P. moehringi Weygoldt \& Peixoto, P. phyllostomus Izecksohn, Cruz \& Peixoto, P. paviotii Cruz, Prado \& Izecksohn, P. renalis (Miranda-Ribeiro), P. subguttata Izecksohn, Cruz \& Peixoto, P. rondonae Prado \& Pombal, and. P. tupinamba Prado \& Pombal (Prado \& Pombal, 2008). The P. bigibbosa group (sensu Kwet \& Faivovich, 2001), characterized by postocular swellings and the absence of prominent palpebral appendages, which includes P. avelinoi Mercadal de Barrio \& Barrio, P bigibbosa (Peters); P. brauni Kwet \& Faivovich, and, P. palustris Giaretta and Sazima. Finally, the P. cristiceps species group (sensu Giaretta et al., 2000), is characterized by both the absence of postocular swellings and shorts palpebral appendages and contains P. cristiceps (Müller), P. goyana (Miranda- Ribeiro), P. cururu Eterovick \& Sazima, P. moratoi (Jim \& Caramaschi), and $P$. concavitympanum Giaretta, Bernarde \& Kokubum. The species $P$. schirchi (Miranda-Ribeiro) is not currently associated to any complex, despite its relationship with P. cristiceps be suggested by Amaro et al., 2009. During field studies on State of Mato Grosso, western Brazil, specimens of Proceratophrys belonging to the cristiceps species group were collected and are herein described as new species.

\section{Material and methods}

Specimens examined are deposited at the Coleção Zoológica de Vertebrados da Universidade Federal de Mato Grosso, Cuiabá,Brazil (UFMT), Museu de Zoologia Adão José Cardoso, Universidade Estadual de Campinas, Campinas, Brazil (ZUEC), Museu de Zoologia João Moojen, Universidade Federal de Viçosa (MZUFV), and 